\title{
Insect Management for Carrots 1
}

\section{S. E. Webb²}

There are no major insect pests on carrot in Florida. The greatest concern for growers has been root damage from soil pests, particularly wireworms (southern potato and tobacco), cutworms (variegated, granulate, black), and mole crickets, all of which are sporadic. Occasional minor pests include leafminers (especially the vegetable leafminer), aphids (green peach and melon), and weevils (especially vegetable weevils). Other arthropods that may occasionally cause minimal damage to carrots in Florida include armyworms (fall, beet, and southern), field crickets, mites (especially twospotted spider mite), and plant bugs (including tarnished plant bug).

Flooding the field during the summer fallow, which was viable in the former muck production areas, has effectively controlled wireworms and other soil insects. However, with the transition from production on organic soils to the inorganic mineral soils of north Florida, flooding is no longer a feasible method of cultural control for most carrot growers. North Florida carrot production will likely require greater insecticide inputs for the management of soil insects.

\section{Cutworms}

Cutworms (Figure 1), a sporadic pest of carrots in Florida, can be a problem during seedling establishment. Cutworms, which are related to armyworms, are thick, dark caterpillars whose adult stage is a moth. They attack young seedlings, most actively at night, and may cut the stem off at the base. During the day, they remain hidden in debris on or just under the soil surface. When disturbed, cutworms curl into a C-shaped ball. Thorough soil preparation in advance of planting helps in cutworm control.

\section{Wireworms, Agriotus spp., Melanotus spp. and other Elateridae}

\section{Description}

Wireworms (Figure 2) are the shiny, hard-bodied, slender larvae of the click beetle. Larvae are brownish yellow and 1/2-1 1/2 inches long. Adults are large, brown beetles that make a clicking sound when they try to right themselves after being on their backs.

1. This document is ENY-462, one of a series of the Entomology \& Nematology Department, Florida Cooperative Extension Service, Institute of Food and Agricultural Sciences, University of Florida. Published: July 2002. Revised: August 2005. For more publications related to horticulture/agriculture, please visit the EDIS Website at http://edis.ifas.ufl.edu/.

2. S. E. Webb, associate professor, Entomology and Nematology Department, Cooperative Extension Service, Institute of Food and Agricultural Sciences, University of Florida, Gainesville, 32611-0640.

The use of trade names in this publication is solely for the purpose of providing specific information. UF/IFAS does not guarantee or warranty the products named, and references to them in this publication does not signify our approval to the exclusion of other products of suitable composition. All chemicals should be used in accordance with directions on the manufacturer's label. Use pesticides safely. Read and follow directions on the manufacturer's label. 


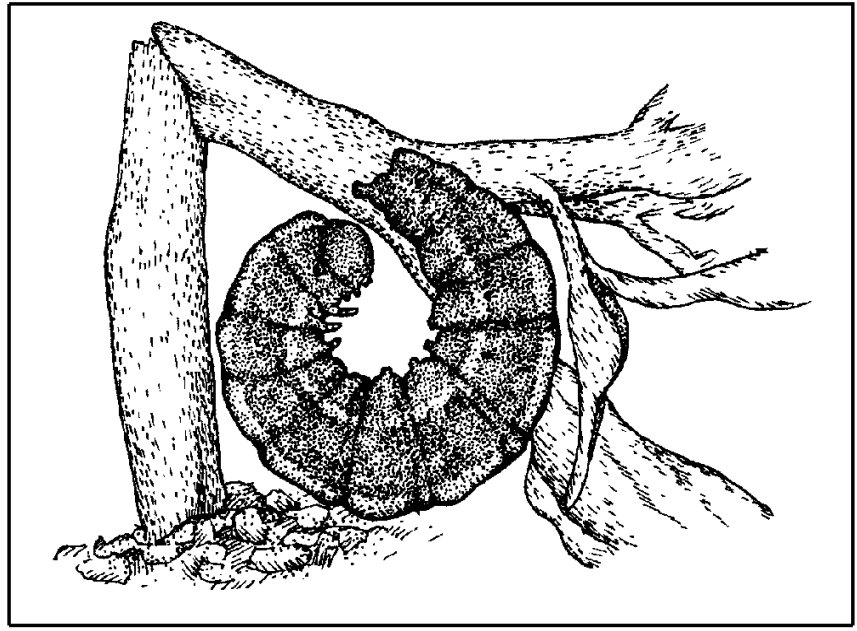

Figure 1. Cutworm.

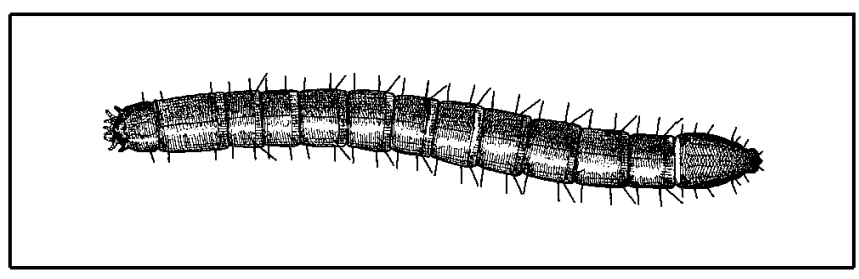

Figure 2. Wireworm larva.

\section{Biology}

Depending on species, wireworm larvae can stay in the soil for 1 to 5 years. Eggs are laid singly in soil 1 to 6 inches deep in spring or summer. Hatching takes place in 2 to 4 weeks. Because of the long egg-laying period, overlapping generations (larvae of different sizes) are present. Adults prefer to oviposit into grassy areas, which include rye, wheat, oats, mixed pastures, old fields, and sometimes potatoes.

\section{Damage}

Wireworms, a sporadic pest on carrots in Florida, are a greater problem on organic soils than on mineral soils. They can attack the developing carrots directly, causing severe loss, or can provide entry points for pathogens that cause secondary rots. See Table 1 for wire management suggestions.
Table 1. Wireworm

\begin{tabular}{|c|c|}
\hline $\begin{array}{l}\text { Managment } \\
\text { Option }\end{array}$ & Recommendations \\
\hline $\begin{array}{l}\text { Scouting/ } \\
\text { thresholds }\end{array}$ & $\begin{array}{l}\text { To determine if wireworms are } \\
\text { present before planting, } 4 \text { to } 5 \text { bait } \\
\text { stations should be placed in the } \\
\text { field } 4 \text { to } 5 \text { weeks before planting. } \\
\text { A station is a hole, approximately } \\
6 \text { inches ( } 15 \mathrm{~cm} \text { ) deep, with a } \\
\text { cupful of untreated wheat and } \\
\text { corn. The hole is covered and in } 2 \\
\text { to } 3 \text { weeks is dug up and checked } \\
\text { for the presence of wireworm } \\
\text { larvae. One wireworm per station } \\
\text { justifies a treatment. }\end{array}$ \\
\hline Note(s) & $\begin{array}{l}\text { Preplant applications of soil } \\
\text { insecticides should be considered } \\
\text { if an area has a history of soil } \\
\text { insect problems (wireworms, } \\
\text { mole crickets, cutworms). }\end{array}$ \\
\hline $\begin{array}{l}\text { Resistant } \\
\text { varieties }\end{array}$ & None available. \\
\hline Site selection & $\begin{array}{l}\text { If possible, avoid areas with a } \\
\text { history of wireworm problems. }\end{array}$ \\
\hline $\begin{array}{l}\text { Other cultural } \\
\text { practices }\end{array}$ & $\begin{array}{l}\text { Planting when the soil is warm } \\
\text { will lessen the chances of } \\
\text { wireworm injury. }\end{array}$ \\
\hline
\end{tabular}

\section{Tawny Mole Cricket, Scapteriscus vicinus; Short-winged Mole Cricket, S. abbreviatus \\ Description}

Of the 10 species of mole crickets (Figure 3), only a few are pests. The tawny mole cricket is the most damaging to vegetable crops. Meandering tunnels created by mole crickets are the most obvious sign of their presence. Approximately $1 / 2$ inch in diameter, tunnels are just below the surface and resemble miniature ground mole tunnels.

\section{Biology}

In the southeastern United States, there is one generation per year. Eggs are laid in chambers, 4 to 12 inches underground, from April through June.

Eggs hatch after about three weeks. The adults of the previous generation die off during May and June and 


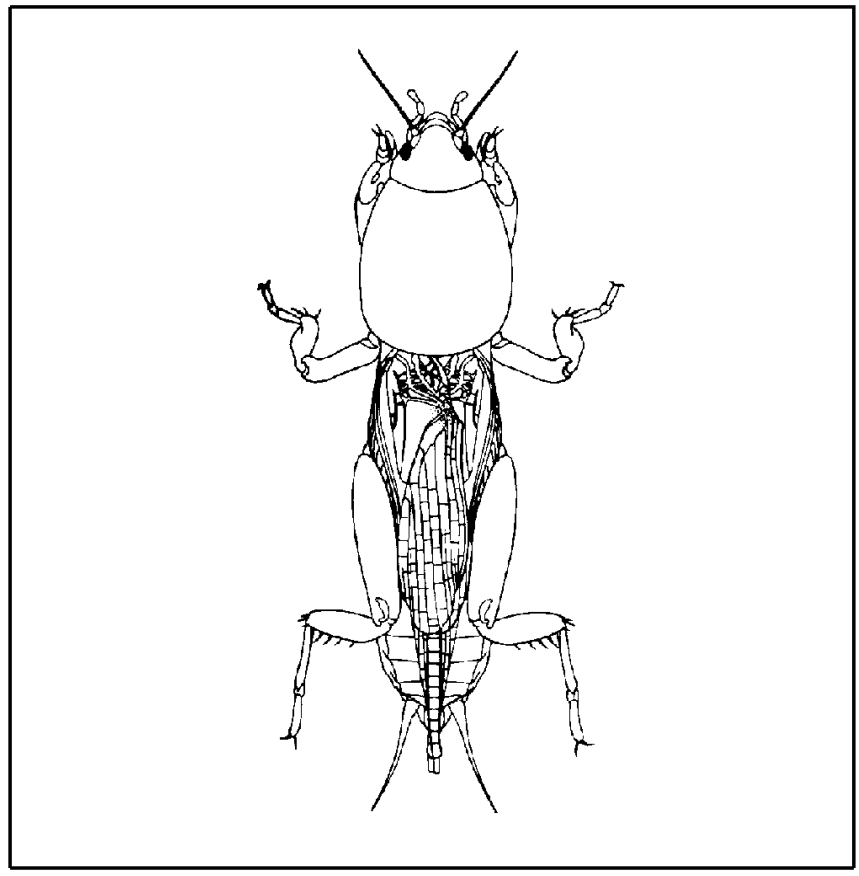

Figure 3. Mole cricket.

most of the new generation reaches the adult stage in the fall and early winter. These adults overwinter and breed in the spring. For two to three months in the spring, tawny mole crickets are most commonly seen during their brief mating flights, which begin shortly after sunset.

\section{Damage}

Mole crickets mainly feed on plant roots. At night, in warm, wet weather, they will also feed on stems and leaves at surface level. Their tunneling in, around, and under the developing root system, in addition to feeding, is particularly damaging to young seedlings. Although some damage occurs from their feeding on the roots and on the stems and leaves of young plants, mole crickets are most damaging to carrot plants when they cut the stems of seedlings at or near ground level.

\section{Management}

In areas where mole crickets are known to cause problems, a preplant application of a soil insecticide that is incorporated into the soil is the most useful control measure. Because of the damage done to pastures and turf, much effort has gone into finding natural enemies of this pest in South America and releasing them in the United States.
The tachinid fly Ormia depleta has been evaluated for use in a classical biological control program for mole crickets, with initial releases made at Gainesville and Bradenton in 1988 and subsequent releases in other counties through 1992. Populations of the fly became established from Dade to Alachua counties but no farther north. This program is still in the experimental stage, with some work focusing on provision of appropriate nectar sources for the fly.

Presently, the most effective biological control agent for mole crickets is a steinernematid nematode introduced from South America. The parasitic nematode Steinernema scapterisci has shown promise for managing mole crickets in pasture and turf in Florida, and in the past has been available commercially for mole cricket control in turf. Steinernema scapterisci has been shown to be highly effective against tawny mole crickets and less effective against short-winged mole crickets. It is most effective as a biocontrol agent where mole cricket populations are highest, as in pastures. It can also be used as a biopesticide where mole cricket populations are lower, and it shows residual activity. The nematode is able to disperse well when applied and has shown good recovery years after its application. Populations have become established in small areas of several Florida counties. If it becomes established in pastures surrounding vegetable crop production areas, it is expected to keep mole cricket populations below damaging levels.

\section{Leafminers, Liriomyza sativae and $L$. trifolii}

\section{Description and Biology}

The adult leafminer (Figure 4) is a small fly, about $1 / 8$ to $1 / 10$ of an inch long with a yellow abdomen. The fly inserts her eggs in feeding punctures on the upper leaf surface. Larvae (maggots) feed between the upper and lower leaf surfaces, creating meandering mines that enlarge as the larvae grow. After approximately two weeks in warm weather the larva completes development and leaves the mine, dropping to the ground to pupate. The complete life cycle can be as short as 18 to 21 days. In Florida, leafminer generations are continuous during most of the year. 


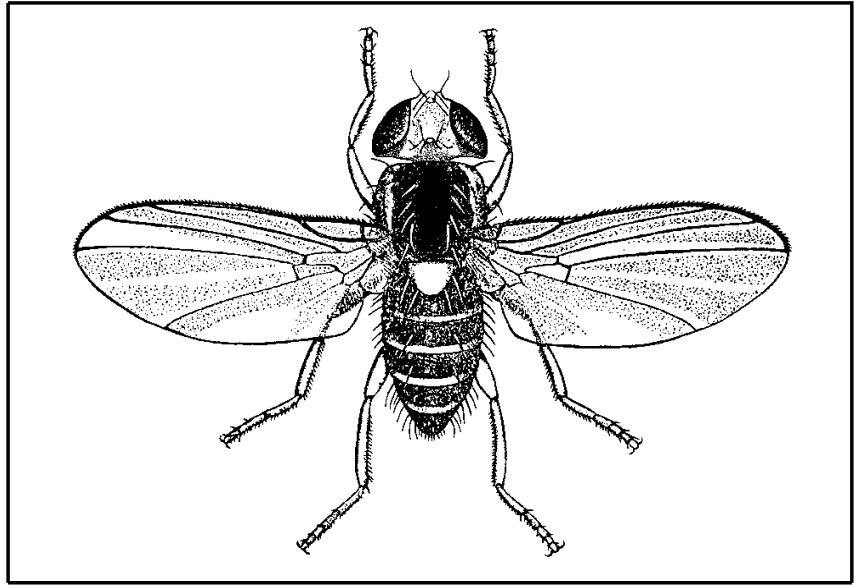

Figure 4. Vegetable leafminer.

\section{Damage}

Leafminers are a sporadic foliar pest on carrots in Florida. Infestations can be more severe late in the growing season, particularly if adults migrate out of nearby crop residue into late-planted fields. They are a problem on seedlings during the fall carrot season. Although healthy plants can usually tolerate substantial leafminer damage, heavy damage may cause leaf drop. Also, the exit holes in old mines may provide access to pathogens.

\section{Management}

Chemical control of leafminers is difficult, because during the feeding stage the pest remains protected within the leaf. Targeting small larvae results in better control. Several parasitic wasps naturally keep populations below damaging levels in Florida in the absence of broad-spectrum insecticide use.

\section{Melon Aphid, Aphis gossypii; Green Peach Aphid, Myzus persicae}

Aphids are also a minor and sporadic pest on carrots in Florida. The green peach aphid (Myzus persicae) is the species most often reported on the crop in the state. The melon aphid (Aphis gossypii), which has a wide host range, may also be found on carrots. The aphid Hyadaphis coriandri, which has recently been found in Florida, is damaging to several umbelliferous herbs and is capable of colonizing carrots, but there has been no state report on carrots.

\section{Description}

Aphids are soft-bodied insects, almost egg-shaped when viewed from above. The largest melon aphids (Figure 5) are not much more than one-sixteenth of an inch in length. The color of melon aphids can vary from pale yellow to orange to dark green to almost black. Green peach aphids (Figure 6) are larger (up to one-tenth of an inch long) and vary in color from pale yellow to medium green. A pair of small tube-like structures called cornicles extends backward and upward from the posterior of the aphid, above a small tail-like structure (cauda). The first individuals to colonize a plant will usually have wings, but then wingless aphids become the dominant form until crowding occurs or the plant deteriorates. Then winged aphids will be produced again to disperse to other plants.

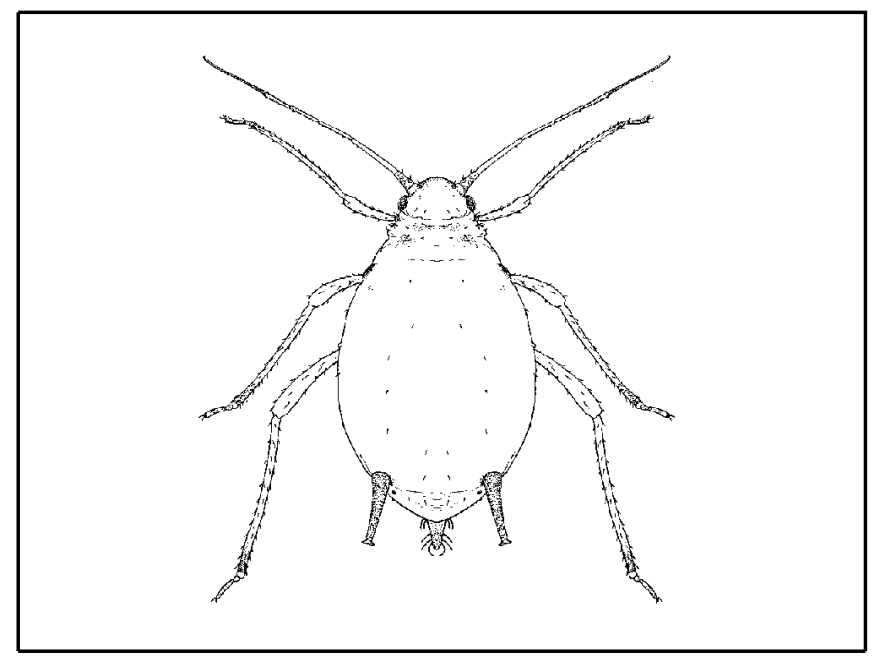

Figure 5. Melon aphid.

\section{Damage}

Aphids feed by piercing plant tissue with their needle-like mouthparts and sucking out water and nutrients. Toxins in their saliva, which can be injected into the plant tissue during feeding, may cause foliage to curl and deform. Aphids also deposit large amounts of honeydew on the plant surface, which encourages the growth of black sooty mold. A short life cycle and reproduction by asexual means and by live birth allow aphid populations to increase rapidly in Florida. 


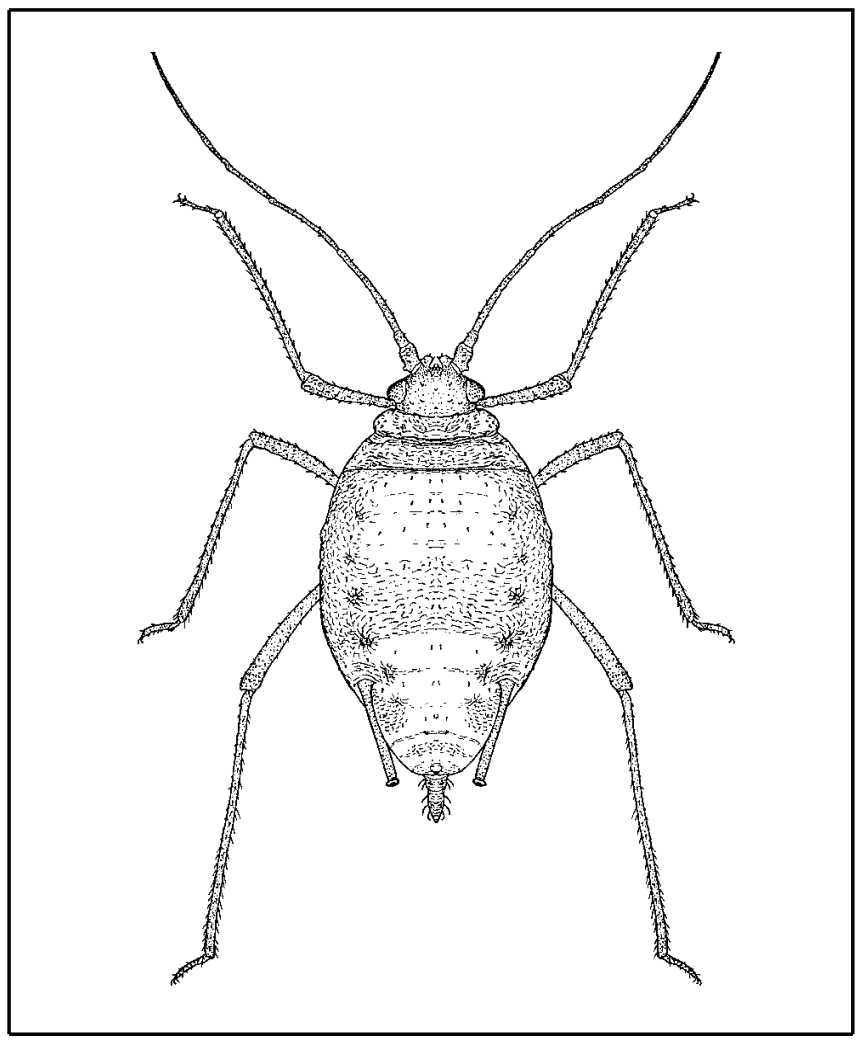

Figure 6. Green peach aphid.

\section{Biological Control}

Beneficial natural enemies such as lady beetles, lacewings, and larvae of syrphid flies feed on aphids. Tiny wasps lay their eggs in aphids. The wasp larva matures inside the living aphid and finally exits, leaving a gold or tan shell (aphid mummy) behind. Occasionally, fungi will infect aphids, drastically reducing populations.

\section{Acknowledgement}

Much of the information above was taken from the Department of Food Science and Human Nutrition, IFAS Publication, Florida Crop/Pest

Management Profiles: Carrots, CIR 1243 (http://edis.ifas.ufl.edu/PI033). 


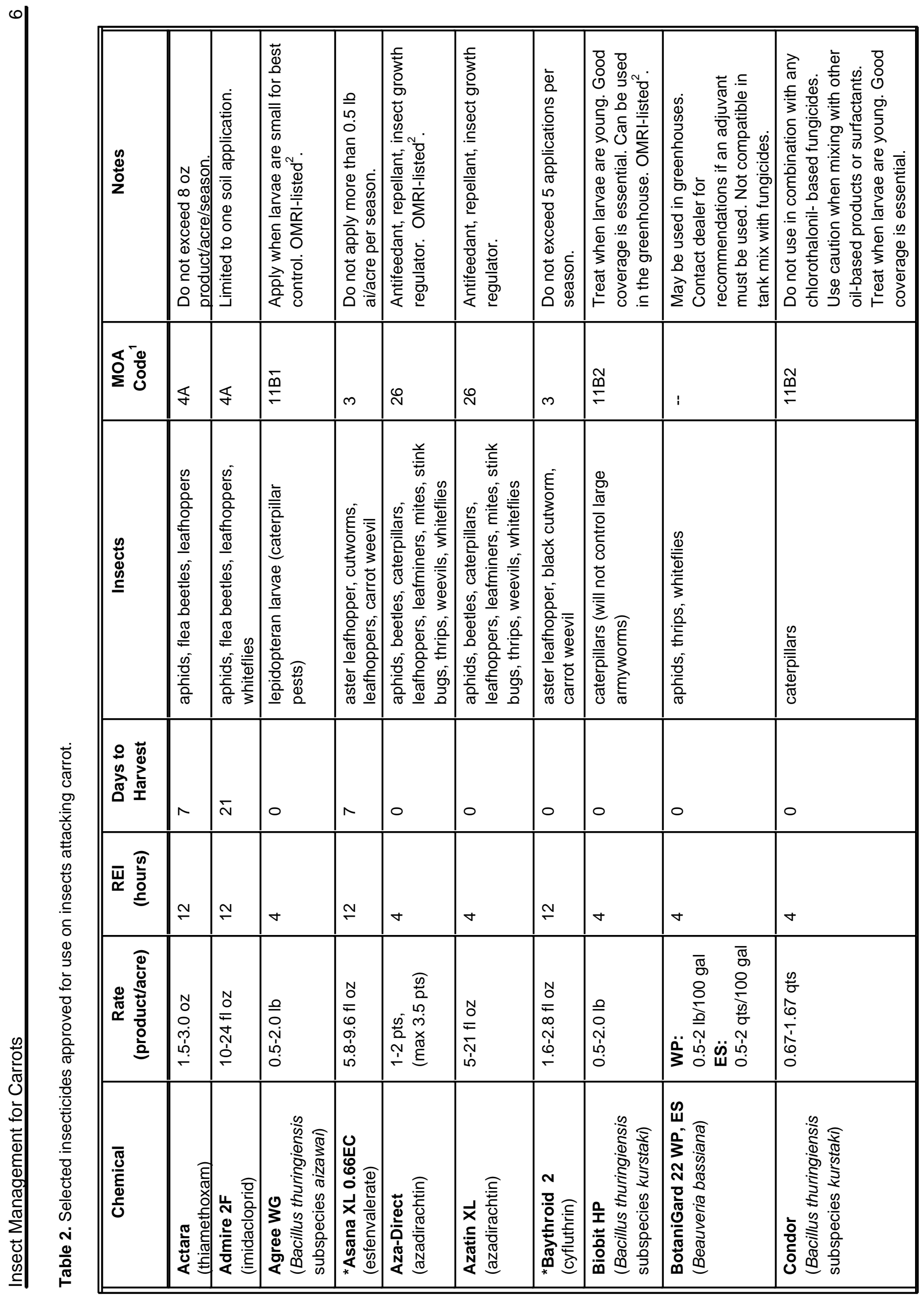




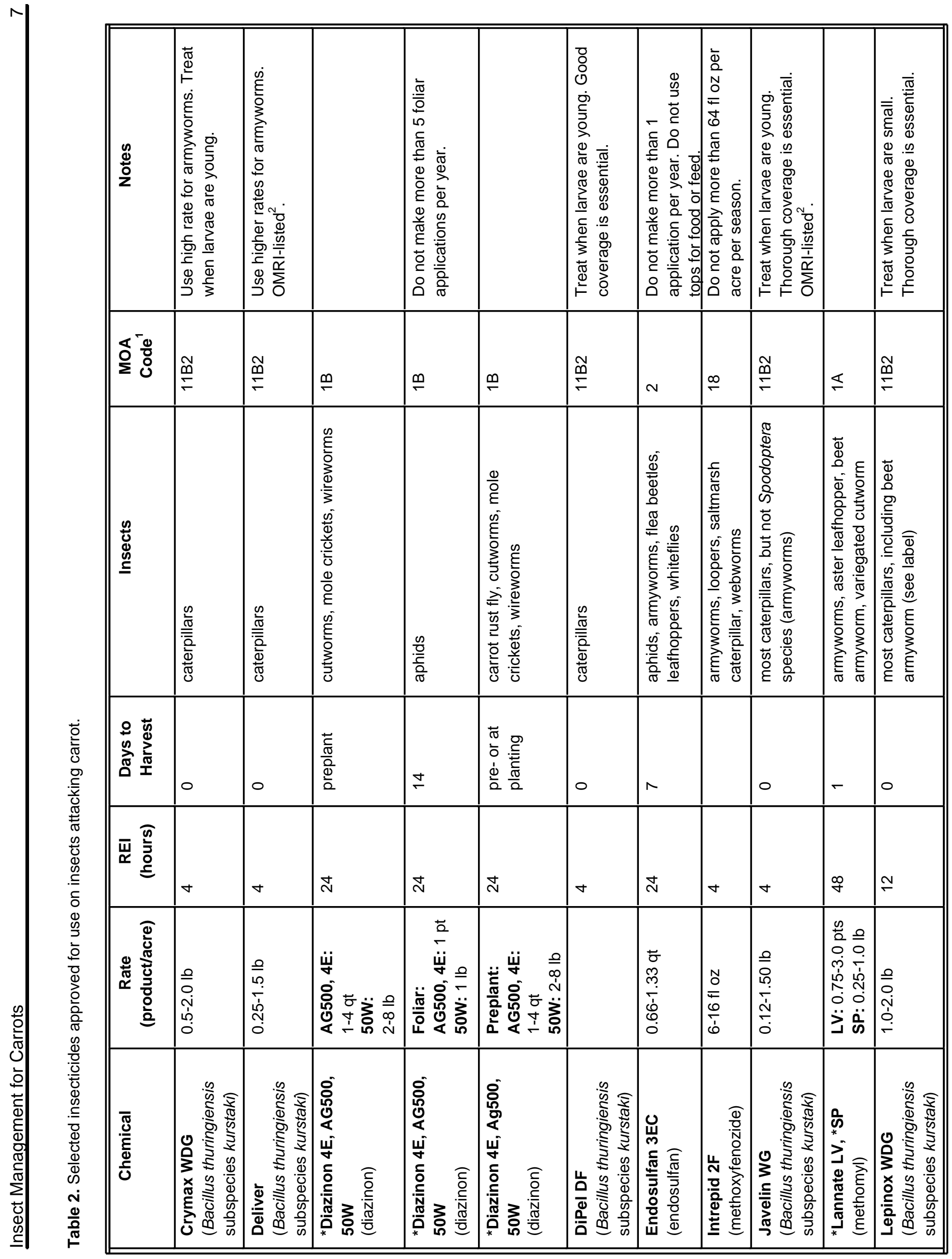




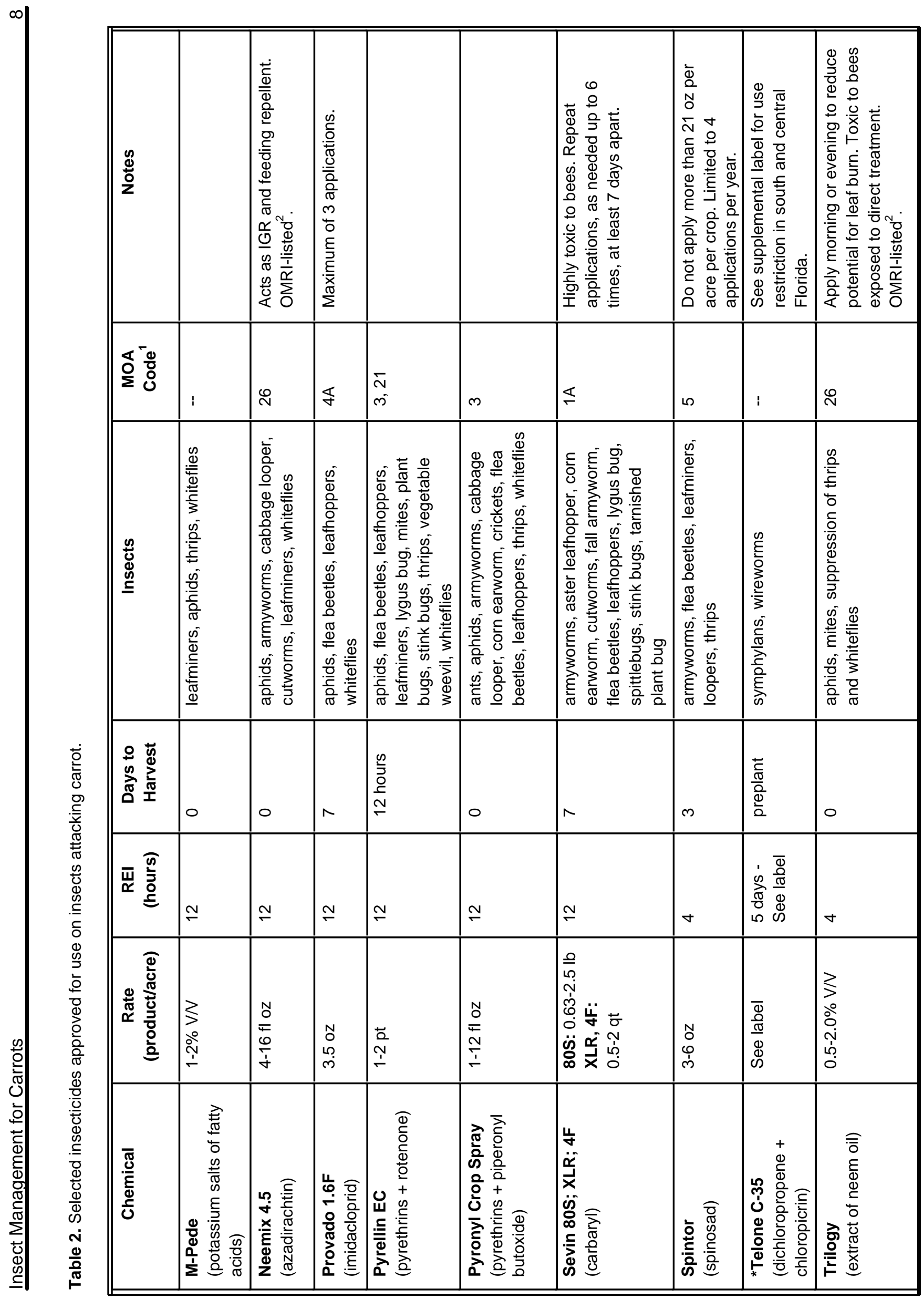




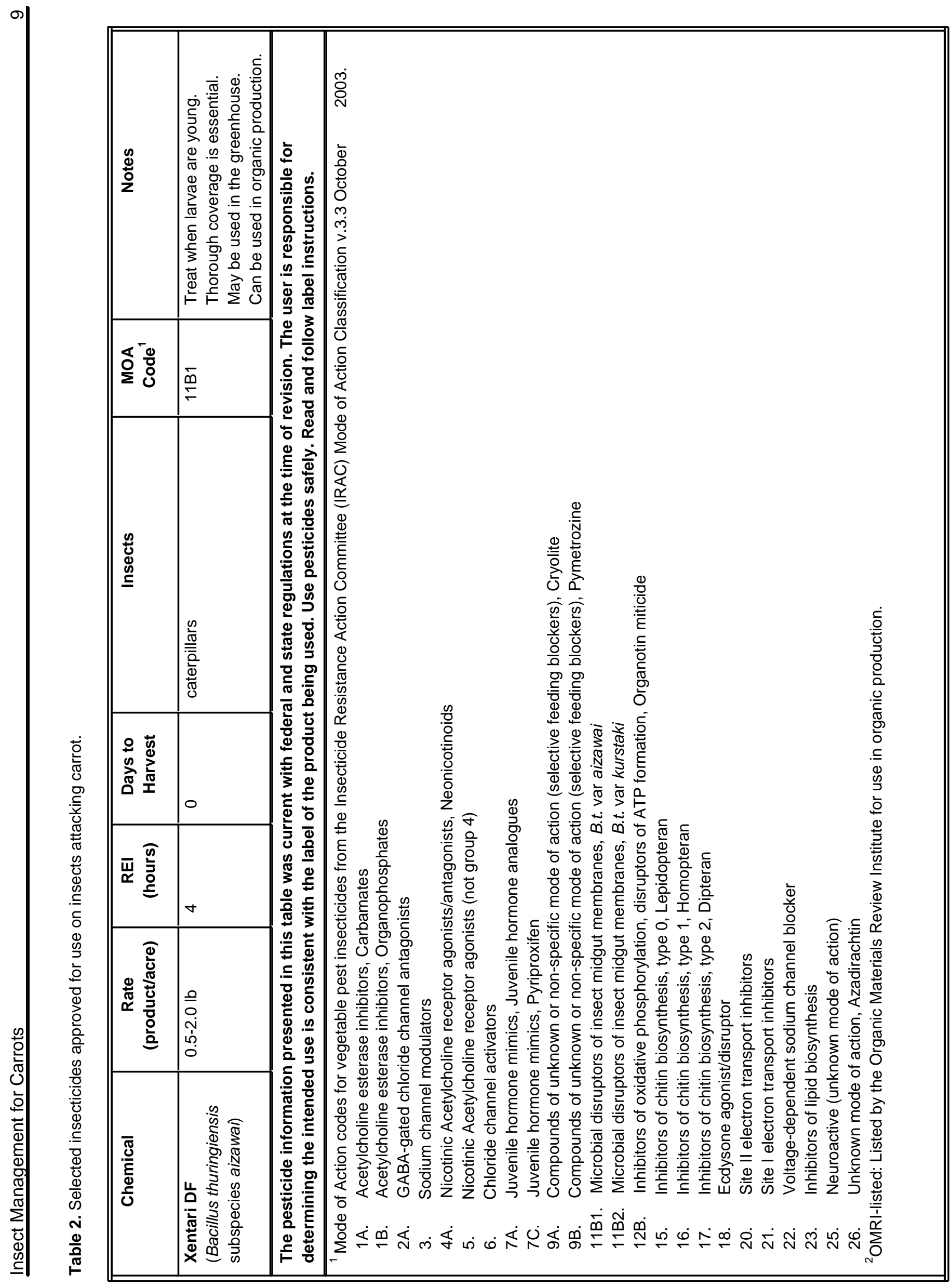

